\title{
PENGARUH DUKUNGAN TEMAN SEBAYA DAN MOTIVASI BELA- JAR TERHADAP PENYESUAIAN DIRI SANTRI
}

\author{
Malini Ulfah \\ maliniulfah@yahoo.co.id \\ HIMPSI Provinsi
}

\begin{abstract}
This study aims to examine effects of peer support and motivation to study on students 'self-adjustment. Sample of this study are $2041^{\text {st }}$ grade students of extention program of Pondok Pesantren Daar el Qolam sebanyak that were gathered using probability sampling technique. Data analysis used in this study was multiple regression analysis with significance level of 0.05. result of this study shows that there are significant effects of peer support and motivation to study on students' self-adjustment. Variance proportion of subjective well-being explained by by all independent variables is $10.1 \%$ whilst the rest is explained by residual. Result of minor hypothesis testing shows that amotivation dimensions of motivation to study has significant effect on self-adjustment. Whilst peer support and type of motivation to study: intrinsic and extrinsic motivation don't jave significant effect on students'self-adjustment.
\end{abstract}

Keyword: peer support, motivation to study, students 'self-adjustment

\begin{abstract}
Abstrak
Penelitian ini dilakukan untuk mengetahui pengaruh dukungan teman sebaya dan motivasi belajar terhadap penyesuaian diri santri. Sampel dalam penelitian ini adalah santri kelas 1. Extention Pondok Pesantren Daar el Qolam sebanyak 204 orang. Teknik sampling yang digunakan adalah probability sampling. Analisis data yang digunakan adalah Multiple Regression Analysis pada taraf signifikansi 0,05. Hasil penelitian menunjukkan bahwa ada pengaruh yang signifikan dukungan teman sebaya dan motivasi belajar terhadap penyesuaian diri santri. Proporsi varians dari subjective well-being yang dijelaskan oleh semua independent variable adalah sebesar 10,1\%, sedangkan 89,9\% sisanya dipengaruhi oleh variabel lain diluar penelitian ini. Hasil uji hipotesis minor menunjukkan bahwa Dimensi amotivation pada motivasi belajar memiliki pengaruh yang signifikan terhadap penyesuaian diri. Sementara itu dimensi dukungan teman sebaya: emotional attachment, social integration, reassurance of worth, reliable alliance, guidance, opportunity for nurturance, dan tipe motivasi belajar: intrinsic motivation dan extrinsic motivation tidak memiliki pengaruh signifikan terhadap penyesuaian diri santri.
\end{abstract}

Kata Kunci: dukungan teman sebaya, motivasi belajar, penyesuaian diri santri 


\section{PENDAHULUAN}

Pada saat ini alternatif pendidikan yang ditawarkan untuk menghasilkan SDM yang berkualitas diantaranya adalah sekolah berasrama (boarding school) yang berada di lingkungan pondok pesantren. Belajar di sekolah berasrama berbeda dengan belajar di sekolah biasa. Secara umum, orang tua menyekolahkan anak di sekolah berasrama dengan pertimbangan memiliki waktu belajar yang lebih panjang dan lebih fokus, memungkinkan anak untuk lebih mandiri dan lebih siap dalam mempersiapkan berbagai macam tantangan yang akan dihadapinya di masa yang akan datang. Siswa-siswa sekolah asrama diwajibkan untuk tinggal di lingkungan sekolah dan sekolah telah menyiapkan tempat untuk para siswa, kegiatan yang dilaksanakan selalu berada di area sekolah (Republika, dalam Zakiyah \& Naili 2010).

Di pondok pesantren, santri dihadapkan kepada kegiatan yang padat. Para santri dituntut untuk mempelajari berbagai mata pelajaran agama dan mata pelajaran umum, serta bergelut dengan keseharian dan rutinitas yang padat. Mulai dari bangun pagi sampai tiba waktu istirahat malam, dan hal ini rutin dilakukan setiap harinya.

Santri baru harus menghadapi perubahan yang terjadi di dalam dirinya tanpa orang tua dan pada lingkungan baru yang menuntut siswa untuk hidup mandiri yaitu asrama di lingkungan pondok pesantren. Asrama santri memiliki keadaan dan peraturan yang jauh berbeda dengan di rumah. Padatnya jadwal yang diterima santri kemudian memberikan dampak lain terhadap pola kehidupannya. Setiap hari santri dibebani oleh kegiatan-kegiatan yang tidak ringan mulai dari bangun tidur hingga tidur kembali diatur sedemikian rupa (Yuniar dkk, dalam Zakiyah,dkk, 2010).

Hal-hal di atas sangat membutuhkan kemampuan santri untuk menyesuaikan diri. Karena penyesuaian diri merupakan suatu konstruk psikologis yang luas dan kompleks, serta melibatkan semua reaksi individu terhadap tuntutan baik dari lingkungan luar maupun dari dalam diri individu itu sendiri (Desmita, 2009).

Penyesuaian diri sendiri bisa dikatakan baik dan bisa tidak baik. Desmita, (2009) menyatakan bahwa individu yang dapat menyelaraskan dirinya dengan tuntutan lingkungannya dengan cara-cara yang dapat diterima dengan lingkungannya, dikatakan sebagai penyesuaian diri yang baik (good adjustment). Sebaliknya, jika reaksi-reaksinya tidak efisien, tidak memuaskan, maka dikatakan sebagai penyesuaian yang kurang baik (bad adjustment).

Kemudian Schneider (1960) menambahkan pernyataan di atas bahwa individu yang good adjustment adalah mereka yang dengan keterbatasan yang ada pada dirinya, telah belajar untuk bereaksi terhadap dirinya sendiri dan lingkungannya dengan cara yang dewasa, bermanfaat, efisien, dan memuaskan, serta dapat menyelesaikan konflik, frustrasi, maupun kesulitan- kesulitan pribadi dan sosial tanpa mengalami gangguan tingkah laku. 
Namun kenyataannya, terdapat suatu fenomena dimana tidak semua individu berhasil dalam melakukan penyesuaian diri dengan berbagai kondisi dan tuntutan dari lingkungannya. Hal ini dapat terlihat dari adanya gejala yang timbul pada seseorang yang mengalami maladjusted (kegagalan dalam menyesuaikan diri) seperti rasa cemas yang berlebihan, kemurungan, depresi, atau gangguan psikosomatis yang dapat menghambat seseorang dalam melakukan aktivitas. Lebih lanjut Schneider (1964) menyatakan bahwa perilaku lain juga terlihat pada seseorang yang tidak mampu mengatasi masalah yang dihadapi sehingga menimbulkan respons dan reaksi yang tidak efektif, situasi emosional yang tidak terkendali, dan keadaan yang tidak memuaskan.

Penyesuaian diri ini juga dibutuhkan oleh santri Pondok Pesantren Daar El-Qolam khususnya bagi santri baru kelas 1 Extention. Santri kelas 1 Estention adalah santri baru lulusan SMP/Mts yang masuk ke pesantren Daar El-Qolam. Santri kelas 1 Estention memiliki kurikulum yang lebih padat dari kelas lainnya, karena program yang tadinya empat tahun kini menjadi tiga tahun (tahun pertama mempelajari seluruh pelajaran agama dan beberapa pelajaran umum kelas 1-3 Mts). Ditambah lagi beban hafalan Al-Qur'an, hafalan naskah pidato dan peraturan di pesantren. Oleh karena itu penyesuaian diri merupakan kebutuhan utama bagi santri di pesantren karena banyak situasi sosial yang berbeda dengan di rumah bisa menjadi sumber tekanan (stresor) sehingga dapat menyebabkan stres.

Pada saat situasi seperti inilah santri diharapkan untuk melakukan penyesuaian dengan berbagai kondisi yang ada sehingga santri mampu mengatasi setiap masalah yang mereka hadapi di pesantren. Beberapa masalah yang biasanya sering dihadapi santri adalah kesulitan dalam menerima otoritas sekolah, tidak menyukai guru mata pelajaran tertentu, kesulitan bergaul dengan teman-teman dan lingkungan, kurangnya disiplin dalam hal waktu, bahkan merasa jenuh dengan rutinitas mereka bersekolah yang dapat menyebabkan stres dan frustrasi. Rumiani (dalam Zakiyah, 2010), menyatakan dalam penelitiannya bahwa dampak dari stress yang dialami siswa adalah kelelahan hingga mengakibatkan turunnya produktivitas dalam belajar maupun aktivitas pribadi.

Terkait masalah penyesuaian diri yang telah dijelaskan sebelumnya, Zakiyah, (2010) juga menemukan sebuah kasus penyesuaian diri pada siswa SMPN 3 Jombang. Dalam penelitian tersebut dikatakan bahwa siswa yang tidak mampu menyesuaikan diri dengan kondisi lingkungan merasa mendapat tekanan, yang menyebabkan stres dan siswa memiliki kecenderungan untuk melakukan aktivitas yang lebih menyenangkan dari pada belajar. Hal inilah yang membuat beberapa siswa dengan tingkat penyesuaian diri rendah lebih memilih membolos pada jam pelajaran tertentu dari pada mengikuti pelajaran tersebut di kelas.

Senada dengan penelitian di atas, peneliti mewawancarai dua orang ustadz dan dua orang ustadzah bagian pengasuhan dan pengajaran pesantren Daar ElQolam (Juli 2013). Mereka menyatakan bahwa santri yang mengalami kesulitan dalam penyesuaian diri, cenderung banyak melakukan pelanggaran kedislipinan, seperti tidak mengenakan seragam lengkap, terlambat masuk sekolah, malas 
melakukan kegiatan ekstrakulikuler dan pergi dari pesantren tanpa izin, sebagian dari mereka penyendiri dan tidak memiliki banyak teman.

Menurut survei peneliti, para santri mengharapkan agar pesantren tidak memiliki peraturan yang terlalu ketat, mengurangi kegiaan yang padat, diperbolehkan membawa barang elektronik, dan lebih meningkatkan fasilitasnya. Namun, pesantren mengharapkan agar santri dapat belajar dengan konsentrasi dan penuh disiplin dalam kesehariannya agar mereka dapat menjadi manusia yang mu'min, muttaqin dan rasikhina fil ilmi.

Dari keterangan di atas, terdapat perbedaan antara keinginan santri dengan keinginan pesantren. Oleh karena itu untuk mengatasi berbagai permasalahan santri di atas, santri diharapkan lebih meningkatkan kemampuan penyesuaian diri mereka agar berhasil untuk mengatasi konflik yang ada di dalam dirinya.

Dari beberapa hasil penelitian di atas, terlihat bahwa penyesuaian diri sangat penting bagi santri. Dengan adanya penyesuaian diri yang baik maka santri dapat beradaptasi dengan semua peraturan yang diterapkan di sekolah, mengikuti kegiatan belajar dengan baik, mencapai prestasi yang tinggi dan memuaskan, tidak bergantung pada orang lain, serta dapat membina hubungan baik dengan guru maupun teman sebaya.

Salah satu unsur yang ada kaitannya dengan penyesuaian diri santri di pesantren adalah dukungan teman sebaya. Penelitian oleh Rahma (dalam Nurdiniyah, 2013) tentang pengaruh dukungan sosial terhadap penyesuaian diri santri kelas I MTs dengan hasil didapat dukungan sosial memberikan kontribusi sebesar 20\% terhadap penyesuaian diri santri kelas I MTs. Selain itu, menurut penelitian Li Shi (2001) dengan judul "Among Students Personal Adjustment in American Culture" diperoleh hasil ada hubungan yang positif antara dukungan sosial dan penyesuaian siswa. Hampir seluruh partisipan menyatakan bahwa dukungan sosial meliputi dukungan dari keluarga, guru, teman sebaya, dan komunitas yang telah membantu mereka menyesuaikan diri dengan sekolah. Dukungan sosial membantu siswa menangani kesulitan yang sulit mereka hadapi di sekolah-sekolah Amerika dan dalam kehidupan baru.

Selain dukungan teman sebaya, ada faktor lain yang mempengaruhi penyesuaian diri santri yaitu motivasi belajar, baik yang berasal dari dalam maupun luar. Santri yang termotivasi untuk belajar, memiliki mental yang kuat untuk bertahan dengan berbagai keadaan dan tuntutan yang ada di pesantren.

Frith (1997) mendefinisikan motivasi sebagai dorongan dari dalam diri yang menghasilkan perilaku. Motivasi membantu seseorang memunculkan potensi dalam diri. Sumber dari luar dapat mempengaruhi perilaku, akan tetapi pada akhirnya itu kekuatan internal dari motivasi yang menopang perilaku. Sedangkan motivasi belajar didefinisikan sebagai kesediaan untuk hadir dan belajar materi yang disampaikan dalam program pengembangan diri (Noe, 1986, dalam Cole, Field \& Harris, 2004).

Dalam penelitian Walls dan Little, (2005) yang berjudul Relations Among Personal Agency, Motivation, and School Adjustment in Early Adolescence 
dinyatakan bahwa keyakinan dan bentuk motivasi pada remaja awal memiliki pengaruh yang kuat terhadap penyesuaian di sekolah. Jika para siswa menempatkan keyakinan pada usaha mereka lebih tinggi dari pada kemampuan mereka, berarti mereka memperkuat nilai penyesuaian di sekolah, disamping peningkatan usaha dengan motivasi diri sendiri. Namun, bentuk dari motivasi dalam self-regulation itu mempengaruhi keyakinan akan usaha dan penyesuaian di sekolah.

Vallerand dan Bissonette, (1992) menyatakan bahwa siswa yang memiliki intrinsic motivation yang baik memiliki emosi yang lebih positif di kelas, lebih menikmati tugas akademik, dan lebih puas dengan sekolah dari pada siswa yang kurang memiliki motivasi.

Sesuai dengan penelitian di atas, Connell dan Wellborn dalam (Deci, Vallerand, Pelletier \& Ryan, 1991) menyatakan bahwa siswa yang termotivasi secara intrinsic dalam mengerjakan tugas sekolah mereka lebih senang berada di sekolah, berprestasi, memiliki pemahaman konseptual, dan lebih memiliki penyesuaian diri yang lebih baik dari pada siswa yang memiliki motivasi yang rendah.

Peneliti tertarik meneliti fenomena ini karena mengingat betapa pentingnya penyesuaian diri santri baik dengan dirinya sendiri maupun dengan lingkungan dan peraturan di pesantren untuk menciptakan hubungan yang harmonis dalam kehidupannya.

Berdasarkan uraian dan fenomena di atas, penulis merasa tertarik untuk melakukan penelitian yang lebih mendalam lagi tentang:"Pengaruh Dukungan Teman Sebaya dan Motivasi Belajar Terhadap Penyesuaian Diri Santri”.

\section{TEORI DAN HIPOTESIS}

\section{Penyesuaian Diri}

Penyesuaian diri diartikan oleh Haber dan Runyon (1984) sebagai suatu perubahan-perubahan yang terbentuk melalui hubungan yang harmonis dengan lingkungan, yang meliputi kemampuan untuk memenuhi kebutuhan individu itu sendiri dan tuntutan serta tekanan dari lingkungannya. Schneiders (1964) mengemukakan bahwa "Penyesuaian diri adalah suatu proses mental dan tingkah laku yang merupakan usaha individu agar berhasil mengatasikebutuhankebutuhan internal, ketegangan, frustasi dan konflik, serta mendorong seseorang untuk menyelaraskan antara tuntutan dalam diri dengan apa yang diharapkan oleh lingkungan".

Calhoun dan Acocella (1990) mendefinisikan penyesuaian diri sebagai interaksi individu yang kontinyu dengan diri sendiri, orang lain dan dengan lingkungan individu tersebut. Good (dalam Raju \& Rahmatulla, 2007), mengartikan penyesuaian diri sebagai proses dalam meraih dan mengadopsi model dari perilaku yang sesuai terhadap lingkungan atau perubahan- perubahan yang terjadi di lingkungan tersebut. Sejalan dengan itu, Shafer (dalam Raju \& Rahmatulla, 2007), mendefinisikan penyesuaian diri adalah proses dimana 
manusia menjaga keseimbangan antara kebutuhan dan hal-hal yang mempengaruhi kepuasan dari kebutuhan tersebut.

Haber dan Runyon (1984) membagi kriteria penyesuaian diri yang efektif menjadi lima bagian:

a. Accurate perception of reality (persepsi yang akurat tentang realita) Hampir setiap orang sepakat bahwa persepsi yang akurat tentang realitas merupakan awalan sebelum menuju pada penyesuaian diri yang baik. Untuk mencapainya dapat dilakukan dengan mengatur tujuan atau capaian secara realistis serta mengenali konsekuensi dan mengarahkan tingkah laku sesuai dengan konsekuensinya.

b. Ability to cope with stress and anxiety (kemampuan mengatasi stres dan kecemasan)

Seseorang mampu bertahan dari keadaan yang tidak menyenangkan (hambatan/ kendala, frustrasi, dan ujian/cobaan), mampu untuk mengatasi konflik atau masalah yang ada, dan melakukan toleransi terhadap usaha keras yang belum juga mencapai tujuan

c. Positive self-image (citra diri positif)

Orang yang memiliki citra diri yang positif akan mampu mempersepsikan tentang dirinya dengan hal-hal yang positif, menyadari dan mengakui kekuatan/ kelebihan diri bahkan menyadari dan mengakui kelemahan/kekurangan diri.

d. Ability to express feelings (kemampuan mengekspresikan perasaan)

Orang yang memiliki penyesuaian diri yang baik tentu mampu mengekspresikan perasaannya. Hal itu dapat dilakukan dengan mengidentifikasi emosi, mengekspresikan berbagai emosi dengan terbuka dan jujur secara secara verbal dan non verbal serta mengekspresikan emosi dengan baik dan memperlihatkan keadaan lingkungan.

e. Good interpersonal relations (hubungan interpersonal yang baik)

Orang yang memiliki hubungan interpersonal yang baik akan mampu berinteraksi dengan orang lain, merasa nyaman dalam berinteraksi dengan orang lain, mampu mencapai kecocokan dan keakraban dalam hubungan social, menghormati orang lain, dapat membuat orang lain merasa nyaman dengan kehadirannya, mampu menghargai hubungan dalam keadaan apapun serta mampu berhubungan dengan orang lain secara produktif saling menguntungkan.

Faktor-faktor yang mempengaruhi penyesuaian diri anak diantaranya: lingkungan tempat anak dibesarkan, model,motivasi untuk belajar melakukan penyesuaian diri dan sosial, bimbingan dan bantuan, dan dukungan teman sebaya. 2. Dukungan Teman Sebaya

Teman sebaya memiliki peran yang cukup penting bagi individu dalam bersosialisasi di dalam masyarakat. Oleh karena itu, dukungan teman sebaya sangat penting bagi individu dalam menjalani kehidupannya. Dukungan teman sebaya itu sendiri merupakan bagian dari dukungan sosial.

Gardner dan Cutrona (2004) mengatakan bahwa dukungan sosial adalah 
komunikasi verbal atau perilaku peduli terhadap kebutuhan orang lain dan memberikan kenyamanan, dorongan, perhatian, atau memberikan pemecahan masalah yang efektif berupa informasi atau bantuan nyata. Gottlieb (1992) menyatakan bahwa dukunga sosial merupakan informasi atau nasihat verbal dan/ atau nonverval, bantuan nyata, atau perbuatan yang dilakukan oleh orang- orang terdekat atu disimpulkan oleh kehadiran mereka dan memiliki manfaat secara emosional atau perilaku terhadap penerimanya. Cobb, Cohens, Wils dan Seeman, (dalam Kim, Sharman \& Taylor, 2008) menerangkan bahwa dukungan sosial adalah informasi dari sesama bahwa seseorang itu dicintai dan dperhatikan, dihargai dan menjadi bagian dari jaringan komunikasi dan tanggung jawab bersama. Ini mungkin datang dari pasangan atau pendamping, kerabat, teman-teman, rekan kerja, dan hubungan masyarakat.

Berdasarkan pengertian di atas, maka peneliti menyimpulkan dukungan teman sebaya adalah pemberian bantuan, perhatian, dan dukungan dari teman sehingga individu merasa diperhatikan, bernilai, dan dicintai.

Weiss (dalam Cutrona,dkk, 1986) mengemukakan adanya enam komponen dukungan sosial yang disebut sebagai "The Social Provision Scale", dimana masing-masing komponen dapat berdiri sendiri, namun satu sama lain saling berhubungan dan digunakan sebagai pengukuran pada dukungan sosial. Adapun komponen-komponen tersebut adalah:

a. Kelekatan emosi (Emotional Attachment) merupakan perasaan akan kedekatan emosional dan rasa aman.

b. Integrasi sosial (Social Intregration) merupakan perasaan menjadi bagian dari keluarga, tempat sesama teman berada dan tempat saling berbagi minat dan aktivitas. Kesamaan minat, perhatian dan rasa memiliki.

c. Adanya pengakuan (Reanssurance of Worth), meliputi pengakuan akan kompetensi dan kemampuan. Penghargaan/pengakuan dari teman.

d. Ketergantungan yang dapat diandalkan (Reliable Reliance), meliputi kepastian atau jaminan bahwa santri dapat mengharapkan sesama teman untuk membantu dalam beragam keadaan. Siswa mencari/mendapat bantuan yang nyata kepada teman.

e. Bimbingan (Guidance) merupakan nasehat dan pemberian informasi oleh teman. Santri dapat saling memberikan masukan/nasehat kepada teman sebaya.

f. Kesempatan untuk mengasuh (Opportunity for Nurturance) merupakan keadaan dimana satri merasa dihargai dan adanya orang lain yang bergantung padanya.

\section{Motivasi Belajar}

Frith, (1997) mendefinisikan motivasi sebagai dorongan dari dalam diri yang menghasilkan perilaku. Motivasi merupakan produk dari beberapa kebutuhan internal. Jadi, ketika seseorang termotivasi, berarti itu bersumber dari pikiran dan perasaannya (Bigge \& Hunt, 1980). 
Motivasi belajar merupakan ketertarikan khusus dalam pendidikan, karena itu merupakan hubungan antara motivasi, kognitif, dan perubahan konseptual (Pintrich, Marx \& Boyle dalam Debacker \& Nelson, 2000). Kemudian Vallerand dan Thill (dalam William, 1998) mendefiisikan motivasi belajar adalah sesuatu hipotesis yang digunakan untuk menggambarkan sumber yang berasal dari dalam dan/atau luar diri dalam mendorong timbulnya semangat, arah, intensitas dan ketekunan dalam belajar.

Lainnya mengatakan bahwa motivasi belajar dibentuk dengan long-term (jangka panjang), peningkatan kualitas belajar dan komitmen untuk belajar (Carole, dalam Lumsden 2009). Menurut Lumsden (1994) motivasi pada diri pelajar secara alami muncul bersama hasrat pelajar untuk berpartisipasi dalam proses belajar. Tetapi juga mencakup alasan-alasan dan tujuan-tujuan atas keterlibatan mereka dalam aktifitas akademik.

\section{Jenis-Jenis Motivasi}

1. Amotivation:

Ryan dan Deci (2000) menjelaskan bahwa amotivation yaitu sebagai bentuk kurangnya niat dalam melakukan sesuatu. Ketika tidak termotivasi, tingkah laku seseorang terlihat kurangnya niat atau hasrat dan kurangnya rasa alasan personal dalam bertindak. Amotivasi adalah hasil dari tidak adanya perhatian terhadap aktifitas, tidak merasa kompeten untuk melakukan sesuatu, atau tidak percaya bahwa sesuatu yang diinginkan akan ada hasilnya.

2. Intrinsic motivation

Ryan dan Stiller (dalam Ryan \& Deci, 2000) mengatakan motivasi intrinsik muncul sebagai fenomena penting pada pendidik, sumber alami dari belajar dan berprestasi yang dapat secara sistematis sebagai penggerak atau dapat berkurang melalui orang tua dan latihan dari guru. Motivasi intrinsik dihasilkan melalui pembelajaran yang berkualitas dan kreatif.

Vallerand et.al, (dalam Barkoukis, 2008) menjelaskan ada beberapa tipe dari motivasi intrinsik, yaitu :

a. Intrinsic motivation to know

Motivasi intrinsik untuk yang mengacu pada keterlibatan dalam kegiatan untuk kesenangan dan kepuasan yang merupakan pengalaman sambil belajar, menjelajahi, atau mencoba memahami sesuatu yang baru (Vallerand et al., 1992).

b. Intrinsic motivation to accomplish

Motivasi intrinsik terhadap prestasi didefinisikan sebagai keterlibatan dalam suatu kegiatan untuk kesenangan dan kepuasan yang diperoleh ketika mencoba untuk unggul, untuk mencapai standar baru, atau untuk membuat sesuatu yang baru.

c. Intrinsic motivation to experience stimulation.

Motivasi intrinsik untuk mengalami stimulasi merupakan keterlibatan dengan kegiatan untuk pengalaman menyenangkan, kegembiraan, dan sensasi positif (Vallerand 1992).

3. Extrinsic motivation 
Ryan dan Deci (2000) menjabarkan motivasi ekstrinsik sebagai konstruk yang berhubungan apabila sebuah aktifitas selesai dilakukan dengan perintah untuk mencapai beberapa hasil yang terpisah. Motivasi ekstrinsik demikian berbeda dengan motivasi intrinsik, yang mana melakukan aktifitas semata-mata hanya untuk kesenangan dari melakukan aktfitas tersebut, dari pada nilai yang yang ada pada aktifitas tersebut.

Ryan dan Deci (2000) dalam teori self-determination nya menjelaskan ada beberapa tipe dari motivasi ekstrinsik, yaitu :

1. External regulation

Begitu tingkah laku ditampilkan untuk memperoleh kepuasan permintaan dari luar atau memperoleh imbalan dari luar yang dibebani. Individu itu biasanya memiliki pengalaman eksternal dalam meregulasi tingkah laku sebagai kontrol. Contoh dari external regulation sebagai berikut; pelajar yang pada awalnya mungkin tidak ingin mengerjakan tugas tetapi tetap dilakukan karena ingin memperoleh imbalan dari guru dan ingin menghindari hukuman.

2. Introjected regulation

Introjected Regulation dijelaskan sebagai tipe dari regulasi internal yang sedikit mengontrol karena seseorang menampilkan tindakan-tindakan dengan perasaan tertekan untuk menghindari rasa bersalah atau kecemasan atau untuk mencapai peningkatan-ego atau kebanggaan.

3. Idenfication

Ryan dan Deci (2000) menjelaskannya sebagai seseorang diidentifikasi melalui kepentingan personal dari tingkah laku mereka dan demikian dapat diterima oleh regulasi sebagai keinginan mereka.

\section{Hipotesis}

Hipotesis Mayor

$\mathrm{Ha}_{1}$ : Ada pengaruh signifikan dukungan teman sebaya dan motivasi belajar terhadap penyesuaian diri santri.

\section{Hipotesis Minor}

$\mathrm{Ha}_{2}$ : Ada pengaruh emotional attachment terhadap penyesuaian diri santri.

$\mathrm{Ha}_{3}^{2}$ : Ada pengaruh social integration terhadap penyesuaian diri santri.

$\mathrm{Ha}_{4}$ : Ada pengaruh reanssurance of worth terhadap penyesuaian diri santri.

$\mathrm{Ha}_{5}$ : Ada pengaruh reliable reliance terhadap penyesuaian diri santri.

$\mathrm{Ha}_{6}$ : Ada pengaruh guidance terhadap terhadap penyesuaian diri santri.

$\mathrm{Ha}_{7}^{6}$ : Ada pengaruh opportunity for nurturance terhadap penyesuaian diri santri.

$\mathrm{Ha}_{8}$ : Ada pengaruh intrinsic motivation terhadap penyesuaian diri santri

$\mathrm{Ha}_{9}$ : Ada pengaruh extrinsic motivation terhadap penyesuaian diri santri.

$\mathrm{Ha}_{10}$ : Ada pengaruh amotivation terhadap penyesuaian diri santri. 


\section{METODE PENELITIAN}

Penelitian ini menggunakan pendekatan kuantitatif dengan analisis multiple regression. Populasi pada penelitian ini adalah santri kelas 1 Extention pondok pesantren Daar el Qolam. Selanjutnya penulis meneliti sampel sebanyak 204 orang dari populasi tersebut secara probability sampling. Skala yang digunakan untuk mengukur penyesuaian diri santri adalah berdasarkan karakteristik penyesuaian diri yang baik menurut Haber dan Ruyon (1984), yaitu: persepsi yang akurat tentang realita (accurate perception of reality), kemampuan mengatasi stres dan kecemasan (ability to cope with stress and anxiety), citra diri positif (positive self image), kemampuan mengekspresikan perasaan (ability to express feelings), dan hubungan interpesonal yang baik (good interpersonal relations). Skala ini terdiri atas 42 item.

Skala yang digunakan untuk mengukur dukungan teman sebaya adalah adaptasi dari The social provisions scale (Cutrona \& Russel, 1987). Skala ini terdiri atas 24 item, namun yang digunakan dalam penelitian ini hanya 23 item

. Skala yang digunakan untuk mengukur motivasi belajar adalah adaptasi dari academic motivation scale Vallerand (1992). Skala ini terdiri atas 28 item.

\section{HASIL PENELITIAN}

Dari hasil analisis multiple regression diperoleh $R 2$ sebesar 0.101 atau $10,1 \%$ artinya penyesuain diri yang dijelaskan oleh semua independent variabel adalah $22.6 \%$ sedangkan $77.4 \%$ sisanya dipengaruhi oleh variabel lain diluar penelitian.

\section{Table 1}

Table Anova

\begin{tabular}{lrrrrrr}
\hline Model & Sum of Squares & df & Mean Square & F & Sig. \\
\hline 1 & Regression & 2.716 & 9 & .302 & 2.426 & $.012^{a}$ \\
& Residual & 24.132 & 194 & .124 & & \\
& Total & 26.848 & 203 & & &
\end{tabular}

Berdasarkan tabel 1, diketahui bahwa $(\mathrm{p}<0.05)$ hal ini menunjukkan bahwa hipotesis nihil(Ho) yang menyatakan bahwa tidak ada pengaruh yang signifikan dari independent variabel terhadap penyesuaian diri siswa, ditolak. Artinya ada pengaruh yang signifikan dari dukungan teman sebaya dan motivasi belajar terhadap penyesuaian diri santri.

Tahapan selanjutnya yaitu melihat koefisien regresi dari tiap independen variable (IV). Koefisien regresi tersebut dapat dilihat pada tabel 2 berikut: 
Tabel 4.2

Coefficients $^{a}$

Model Coefficients

Standardized Coefficients

Unstandardized

\begin{tabular}{|c|c|c|c|c|c|c|}
\hline \multirow[t]{10}{*}{1} & (Constant) & 54.709 & 5.736 & & 9.538 & .000 \\
\hline & t_emotionalattachment & .007 & .056 & .011 & .132 & .895 \\
\hline & t_socialintegration & .055 & .044 & .098 & 1.260 & .209 \\
\hline & t_reanssuranceofworth & .006 & .034 & .014 & .169 & .866 \\
\hline & t_reliabelreliance & -.045 & .079 & -.046 & -.575 & .566 \\
\hline & t_guidance & .035 & .049 & .055 & .711 & .478 \\
\hline & t_opportunityfornurturance & -.016 & .017 & -.067 & -.916 & .361 \\
\hline & t_instrinsik & .000 & .047 & .000 & -.003 & .998 \\
\hline & t_ekstrinsik & -.018 & .045 & -.027 & -.391 & .696 \\
\hline & t_amotivation & -.118 & .040 & -.235 & -2.939 & .004 \\
\hline
\end{tabular}

Dari hasil diatas koefisien regresi amotivation yang signifikan, sedangkan yang lainnya tidak. Hal ini menunjukkan bahwa dari sembilan hipotesis minor terdapat satu yang signifikan. Dengan demikian dapat disusun persamaan regresi pada penyesuaian diri, yaitu :

Penyesuaian Diri $=54.709+0.007 *$ Emotional Attachment $+0.055^{*}$ Social Integration $+0.006^{*}$ Reanssurance of Worth - 0.045*Reliable Reliance + $0.035^{*}$ Guidance $0.016^{*}$ Opportunity for Nurturance $+0.000 *$ Intrinsik $0.018 *$ Ekstrinsik $-0.118 *$ Amotivation

Penjelasan dari nilai koefisien regresi yang diperoleh pada masing-masing IV sebagai berikut :

1. Variabel emotional attachment dimensi dukungan teman sebaya memiliki nilai koefisien regresi sebesar 0,007 atau 0,7\%. Hal ini menunjukkan bahwa variabel emotional attachment secara positif mempengaruhi penyesuaian diri. Artinya, semakin besar skor emotional attachment maka semakin tinggi penyesuaian diri. Kemudian dilihat dari nilai $\mathrm{P}=0,895>0,05$, maka variabel emotional attachment tidak signifikan pengaruhnya terhadap penyesuaian diri.

2. Variabel social integration dimensi dukungan teman sebaya memiliki nilai koefisien regresi sebesar 0,055 atau 5,5\%. Hal ini menunjukkan bahwa variabel social integration secara positif mempengaruhi penyesuaian diri. Kemudian dilihat dari nilai $\mathrm{P}=0,209>0.05$, maka variabel social integration tidak signifikan pengaruhnya terhadap penyesuaian diri. 
3. Variabel reanssurance of worth dimensi dukungan teman sebaya memiliki nilai koefisien regresi sebesar 0,006 atau $0,6 \%$. Hal ini menunjukkan bahwa variabel reanssurance of worth secara positif mempengaruhi penyesuaian diri. Kemudian dilihat dari nilai $\mathrm{P}=0,866>0.05$, maka variabel reanssurance of worth tidak signifikan pengaruhnya terhadap penyesuaian diri.

4. Variabel reliable reliance dimensi dukungan teman sebaya memiliki nilai koefisien regresi sebesar $-0,045$ atau $-4,5 \%$. Hal ini menunjukkan bahwa variabel reliable reliance secara negatif mempengaruhi penyesuaian diri. Artinya, semakin besar skor reliable reliance maka semakin rendah penyesuaian diri. Kemudian dilihat dari nilai $\mathrm{P}=0,566>0.05$, maka variabel reliable reliance tidak signifikan pengaruhnya terhadap penyesuaian diri.

5. Variabel guidance dimensi dukungan teman sebaya memiliki nilai koefisien regresi sebesar 0,035atau 3,5\%. Kemudian dilihat dari nilai $\mathrm{P}=0,478>0.05$, maka variabel guidance tidak signifikan pengaruhnya terhadap penyesuaian diri.

6. Variabel opportunity for nurturance dimensi dukungan teman sebaya memiliki nilai koefisien regresi sebesar $-0,016$ atau $-1,6 \%$. Hal ini menunjukkan bahwa variabel opportunity for nurturance secara negatif mempengaruhi penyesuaian diri. Artinya, semakin besar skor opportunity for nurturance maka semakin rendah penyesuaian diri. Kemudian dilihat dari nilai $\mathrm{P}=0,361>0.05$, maka variabel opportunity for nurturance tidak signifikan pengaruhnya terhadap penyesuaian diri.

7. Variabel instrinsic dimensi motivasi belajar memiliki nilai koefisien regresi sebesar 0,000 atau $0 \%$. Kemudian dilihat dari nilai $\mathrm{P}=0,998>0.05$, maka variabel instrinsic tidak signifikan pengaruhnya terhadap penyesuaian diri.

8. Variabel extrinsic dimensi motivasi belajar memiliki nilai koefisien regresi sebesar - 0,018atau -1,8\%. Hal ini menunjukkan bahwa variabel extrinsic secara negatif mempengaruhi penyesuaian diri. Artinya, semakin besar skor extrinsic maka semakin rendah penyesuaian diri. Kemudian dilihat dari nilai $\mathrm{P}=0,696>0.05$, maka variabel extrinsic tidak signifikan pengaruhnya terhadap penyesuaian diri.

9. Variabel amotivation dimensi motivasi belajar memiliki nilai koefisien regresi sebesar - 0,118atau -11,8\%. Hal ini menunjukkan bahwa variabel amotivation secara negatif mempengaruhi penyesuaian diri. Artinya, semakin besar skor amotivation maka semakin rendah penyesuaian diri. Kemudian dilihat dari nilai $\mathrm{P}=0,004<0.05$, maka variabel amotivation signifikan pengaruhnya terhadap penyesuaian diri. 
Table 3

Proporsi Varians

\begin{tabular}{llllllllll}
\hline 1 & $.163^{\mathrm{a}}$ & .027 & .022 & .35968 & .027 & 5.532 & 1 & 202 & .020 \\
2 & $.211^{\mathrm{b}}$ & .044 & .035 & .35726 & .018 & 3.740 & 1 & 201 & .055 \\
3 & $.211^{\mathrm{c}}$ & .044 & .030 & .35815 & .000 & .003 & 1 & 200 & .956 \\
4 & $.212^{\mathrm{d}}$ & .045 & .026 & .35892 & .001 & .144 & 1 & 199 & .705 \\
5 & $.219^{\mathrm{e}}$ & .048 & .024 & .35930 & .003 & .581 & 1 & 198 & .447 \\
6 & $.240^{\mathrm{f}}$ & .057 & .029 & .35840 & .010 & 1.995 & 1 & 197 & .159 \\
7 & $.245^{\mathrm{g}}$ & .060 & .027 & .35879 & .003 & .573 & 1 & 196 & .450 \\
8 & $.247^{\mathrm{h}}$ & .061 & .023 & .35954 & .001 & .187 & 1 & 195 & .666 \\
9 & $.318^{\mathrm{i}}$ & .101 & .059 & .35269 & .040 & 8.640 & 1 & 194 & .004 \\
\hline
\end{tabular}

Dengan demikian, dapat disimpulkan bahwa terdapat dua independent variabel yakni, emotional attachment sebesar 0.027 atau 2,7\%.dan amotivation 0.040 atau $4 \%$ yang secara statistik memberikan sumbangan yang signifikan terhadap penyesuaian diri.

\section{DISKUSI}

Pada penelitian ini, dari enam dimensi dukungan teman sebaya yaitu emotional attachment, social integration, reanssurance of worth, reliabel reliance, guidance, opportunity for nurturance, diperoleh hasil bahwa tidak satupun yang memberikan pengaruh yang signifikan terhadap penyesuaian diri.

Dukungan teman sebaya tidak signifikan mempengaruhi penyesuaian diri diasumsikan karena santri memiliki sistem belajar yang individual, seperti menghafal Al-Quran, kosa kata bahasa Arab dan Inggris, naskah pidato, dan pelajaran sekolah, minimnya diskusi di kelas (guru mangajar dengan metode ceramah), dan tidak ada tugas kelompok. Sistem inipun berlaku di asrama, santri yang tercatat sebagai pelanggar peraturan diwajibkan untuk mencari dan memata-matai santri lain yang melanggar hukum untuk dilaporkan ke santri pengurus untuk diberi sanksi, ini dilakukan secara individu dan rahasia. Hal ini pun didukung oleh hasil kategorisasi dimensi-dimensi dukungan teman sebaya yang sebagian besar rendah.

Hal ini tidak sesuai dengan penelitian Kumalasari dan Ahyani (2012) yang menunjukkan bahwa ada hubungan dukungan sosial dengan penyesuaian diri remaja di panti asuhan. Hal ini menunjukkan bahwa dukungan sosial berpengaruh terhadap penyesuaian diri pada remaja.

Sejalan dengan penelitian di atas, Paulina (2008) meneliti tentang dukungan sosial teman sebaya dan penyesuaian diri remaja pada siswa kelas $\mathrm{X}$ dan kelas XI di SMA Widya Gama. Hasil penelitian tersebut menunjukkan bahwa terdapat 
hubungan positif yang signifikan antara dukungan sosial teman sebaya dengan penyesuaian diri remaja pada siswa, dengan $r$ sebesar $0,547(p=0,0000,05)$

Namun, jika dilihat dari besarnya sumbangan varians, maka terdapat satu variabel yang memberikan sumbangan signifikan sebesar 2,7\% yaitu emotional attachment (kelekatan emosi). Hasil ini sesuai dengan penelitian yang dilakukan oleh Mila (2010) bahwa kelekatan emosi dengan teman memiliki pengaruh terhadap penyesuaian diri dengan sumbangan efektif kelekatan terhadap penyesuaian diri sebesar $26,1 \%$.

Tidak adanya dukungan sosial dapat menimbulkan perasaan kesepian dan kehilangan yang juga dapat mengganggu proses penyesuaian diri. Hal senada juga diungkapkan oleh Shah (2012) bahwa anak yang sulit bergaul dengan teman sebaya lebih cenderung memiliki perilaku yang negatif di sekolah, memiliki hubungan yang buruk dengan guru, bolos sekolah, memiliki prestasi yang buruk, dan tinggal kelas. Kehadiran sumber dukungan yang sesuai dapat membantu penyesuaian diri individu dalam menghadapi peristiwa-peristiwa yang menekan.

Remaja yang berhubungan erat dengan orang tua dan teman sebaya memiliki penyesuaian diri yang baik, sebaliknya remaja dengan hubungan yang kurang erat dengan orang tua dan teman sebaya memiliki penyesuaian diri yang buruk. Selanjutnya, remaja yang berhubungan baik dengan teman sebaya, namun kurang berhubungan baik dengan orang tua memiliki penyesuaian diri yang lebih baik dari pada remaja yang berhubungan baik dengan orang tua, namun kurang berhubungan baik dengan teman sebaya (Laible, et.al. 2000). Hal ini tidak sesuai dengan hasil penelitian peneliti karena dalam penelitian ini santri yang memiliki penyesuaian diri yang tinggi dan rendah berjumlah seimbang yaitu 50:50.

Selanjutnya, hasil penelitian ini juga menunjukkan bahwa dari tiga dimensi motivasi belajar, terdapat satu variabel yang signifikan mempengaruhi penyesuain diri, yaitu amotivation sebesar 4\%. Dalam hal ini amotivation dan penyesuain diri berbanding terbalik. Artinya dalam penelitian ini semakin rendah amotivation maka santri semakin mampu menyesuaikan diri.

Motivasi intrinsic tidak signifikan mempengaruhi penyesuain diri. Hal ini tidak sesuai dengan hasil penelitian Korb (2012) yang menyatakan bahwa intrinsic motivation memiliki pengaruh yang signifikan terhadap penyesuaian diri siswa di Nigeria. Ketidaksesuain ini diasumsikan karena sebagian besar dari santri memilikitingkat intrinsic motivation yang rendah. Extrinsic motivation dalam penelitian ini juga tidak signifikan mempengaruhi penyesuaian diri, Hal ini sesuai dalam penelitian Korb (2012) yaitu extrinsic motivation tidak signifikan mempengaruhi penyesuaian diri siswa.

Hal ini tidak sesuai dengan penelitian Munawwaroh (2009) yang menyatakan bahwa ada hubungan positif yang signifikan (rhitung $=0,405>$ rtabel $=0,312$ ) antara motivasi belajar dengan penyesuaian diri santri Pondok Pesantren Al-Islahiyah dengan proporsi ralat 0,000 .

Deci, Vallerand, Pelletier \& Ryan (1991) menyatakan bahwa pelajar yang 
memiliki amotivation tinggi sulit menyesuaikan diri di sekolah, pendiam dan lebih suka menyendiri. Sejalan dengan itu, Vallerand dan Bissonette (1992) mengemukakan bahwa amotivation cenderung dimiliki oleh remaja yang memiliki sedikit teman. Orang yang memiliki amotivation tinggi cenderung memiliki perilaku negatif yang menetap ketimbang orang yang memiliki nilai amotivation rendah.

Motivasi dalam self-determination berhubungan dengan perilaku positif siswa, seperti merasa nyaman di sekola (Ryan \& Connel, dalam Vallerand, Miquelon, Grouzet \& Cardinal, 2005), emosi yang positif di kelas, menikmati tugas akademik dan puas dengan sekolah (Vallerand, Blais, Brière \& Pelletier, 1989, dalam vallerand, et.al., 2005), sebaliknya siswa yang tidak memiliki motivasi mengalami coping yang buruk dalam mengatasi kegagalannya, kurang memiliki emosi yang positif di sekolah, cemas, dan depresi. Oleh sebab itu, motivasi dalam teori self-determination di sekolah berpengaruh positif dengan penyesuian diri yang lebih baik (Vallerand, Miquelon, Grouzet \& Cardinal, 2005).

\section{Saran}

\section{Saran teoritis}

1. Variasi dari kesembilan independent variable (IV) yang ada, hanya menyumbang 10,1\%. Sisanya sebanyak 89,9\% kemungkinan disumbangkan oleh variabel lainnya. Variabel yang tidak diteliti pada penelitian ini memberikan sumbangan yang lebih besar daripada variabel yang diteliti. Dan dari kesembilan IV yang diteliti, hanya variabel amotivation yang memiliki pengaruh signifikan terhadap penyesuaian diri. Oleh sebab itu, disarankan untuk penelitian selanjutnya agar meneliti pengaruh variabel-variabel lain yang dapat mempengaruhi penyesuaian diri terutama pada santri selain yang ada pada independent variable penelitian ini, seperti: self-esteem, selfconcept, dan kepribadian.

2. Pada penelitian selanjutnya disarankan untuk menggunakan sampel lain selain santri pondok pesantren, seperti siswa SMA, SMK atau boarding school non pesantren (dengan latar belakang agama yang berbeda).

\section{Saran praktis}

1. Bagi para santri hendaknya lebih memberikan dukungan dan perhatian terhadap sesama teman agar dapat terjalin keakraban dan kelekatan emosional antar satu sama lain.

2. Bagi pihak Pesantren disarankan memfasilitasi santri dengan adanya guru bimbingan konseling untuk membantu santri dalam pengembangan diri dan menjembatani santri agar lebih dekat satu sama lain. Guru Bimbingan dan Konseling dapat membuat kegiatan kelompok, misalnya role playing, modelling, sosiodrama, atau "konselor sebaya".

3. Bagi bagian pengajaran pesantren untuk memberikan pemahaman mengenai goal setting pada santri, agar santri lebih termotivasi untuk belajar dan 
mengetahui tujuan dari belajar di pesantren.

4. Bagi guru diharapkan membentuk kelompok-kelompok diskusi di kelas untuk membina hubungan teman sebaya.

$* * * * * *$

Std. Error

Change Statistics

Model R

R Square

Adjusted R Square

of the Estimate

R Square

Change F Change df1 df2

Sig. F Change

$* * * * * *$ 